\title{
Dimensions of State Political Party Organizations
}

Sarah M. Morehouse, University of Connecticut

A political party is defined in terms of coalition building: collective effort directed toward capturing public office and governing once that office is attained. Party organization thus defined includes factional organization as well as the administrative apparatus. This definition assumes a linkage between the electoral party and the party inside the government.

Party organization matters and the scholars in this volume are committed to investigating and understanding it. We have accepted Leon Epstein's challenge to study state party organizations in and out of government using quantitative methods as well as field observation $(1993,472)$. This volume presents the results of nine research projects, all of which compare political party organizations in more than one state, some among many states. The purpose of this introductory essay is to define party organization and put into perspective the research included herein.

\section{Definition of Party as Coalition Building}

A party may be defined in terms of coalition building: collective activity directed toward capturing public office and governing once that office is attained (Epstein 1986, 3; Downs 1957, 34; Schlesinger 1991, 6). Most definitions of political parties as organizations assume the electoral and the governing functions. Those who criticize Anthony Downs' definition of party (i.e., "a team seeking to control the governing apparatus by gaining office in a duly constituted election") as too devoid of policy commitment fail to recognize that his whole theory of parties is based on the distribution of voter preferences. Without the desire to win elections as a leading motive, candidates need not pay attention to the preferences of the people.

\section{Party Coalitions and Party Voters}

This concept of party is the party coalition that organizes to elect and govern. It links two of the three parts of the traditional tripartite definition of party. The concept does not include the voters as part of the

SARAh M. MORehouse is Professor Emeritus of Political Science at the University of Connecticut.

The American Review of Politics, Vol. 15. Summer, 1994: 123-139

${ }^{\circledR} 1994$ The American Review of Politics 
party organization; however, as explained above, the preferences of the voters are the base of party organization. The voters are choosers among competing parties. Because they are less committed partisans than they were before does not mean that the parties as organizations are weaker. In fact, Schlesinger believes that the more flexible the electorate, the more the party must organize to convince these discriminating voters (Schlesinger 1991, 192-199). Or, as Pomper states, parties are to be examined as "groups of people who seek power through the ballot box, not as voters who grant power through their ballots" (Pomper 1992, 5).

\section{Party Coalitions and Party Bureaucracies}

The concept of party as an electoral and governing organization includes the candidate coalitions as well as the formal party apparatus. State party bureaucracies have become stronger in recent years. The Party Transformation Study which was the work of four political scientists (Cotter, Gibson, Bibby and Huckshorn 1984) documented the growth in strength of state and local organizations over a 20 year period (1960-1980). They found that state budgets had grown and that over 90 percent of the parties had either full-time state chairs or executive directors. The revivified state party bureaucracies ran campaign seminars for party candidates and a majority of them had mobilization programs through which to identify and turn out their party's likely voters. Many parties were increasingly active in providing campaign services to candidates. These findings were confirmed by the Advisory Commission on Intergovernmental Relations' survey of state party chairs in 1983-1984 (1986, 111-118).

The relationship between increased bureaucratic strength and winning elections has not been proven. The authors of the Party Transformation Study documented the fact that Republican state party bureaucracies were considerably stronger than their Democratic counterparts. In several southern states where the Republicans have not yet achieved electoral strength, they have built up the party apparatus in anticipation of attracting votes. Therefore we would not expect an immediate correlation between bureaucratic organization and electoral strength. Leaving out the southern states for that reason, the authors test for party organizational strength (POS, as they call it), and party electoral success in contests for governor. Their findings show that the relative strength of Democratic state party organization correlates .46 with Democratic electoral success (Cotter, Gibson, Bibby and Huckshorn 1984, 93-104). This is a modest correlation, but in the right direction. 
The coalitions that candidates build to receive the party nomination may be related to the party's bureaucratic strength. We do not know how this increased organizational capability matters to candidates for the gubernatorial nomination. Most state parties, even those with ample budgets, hold back on campaign contributions and fund-raising assistance until a candidate emerges from the primary process. I predict that strong party leadership can commit effort and resources to their favored candidate for the endorsement and the following primary.

\section{Party Coalitions and Responsible Parties}

The advocates of responsible party government want to transcend the purely electoral operation of American political parties and make them vehicles for policy-making. Policy is to be determined by assessing the public interest, and by consensus among party activists. Proponents of responsible party government promote ideologically distinct political parties which are strongly disciplined and cohesive. The parties are responsible to the electorate because they fear losing the next election. They are cohesive because they know that disunity may bring defeat (Ranney 1962, 8-22).

The responsible parties model emphasizes the policy motivations of party elites who participate in politics to achieve policy or ideological goals, while the party coalition model emphasizes electoral incentives. In the responsible parties model, the party elites push the party away from the center in order to remain ideologically pure. In the party coalition model, the elites push the party toward the center in order to win. Which of these two models represents reality?

In Statehouse Democracy, Erikson, Wright and McIver (1993) resolve the apparent conflict between the two models by examining the ideological preferences of two groups of elites within each political party: the activist elite and the electoral elite. For the activist elite (e.g., convention volunteers, contributors, convention delegates, and party officials), maintaining ideological purity and distance from the opposite party is preferable. For the electoral elite (i.e., those who seek and are elected to office), appealing to the ideologically moderate center where more voters are is a strategic necessity. Hence, each party is torn between these two ideological elites, and every election represents a compromise between elites that are ideologically driven and elites that are electorally driven. 


\section{Party Coalitions and Party Government}

Party organization matters. It matters to candidates for governor whether they can count on party resources to win the nomination. It matters whether legislators identify with the party and commit to the platform, because they can be counted on to support it in the legislative session. These are minimal conditions for political parties to fulfill, and they are possible under our system.

Ambition is not as noble a motive as "responsibility," but it is a more accurate description of the propelling force behind political party organizations in the American states. Anthony Downs says that political parties formulate policies to win elections instead of winning elections to formulate policy $(1957,27-28)$.

If electoral ambition is the dominant motive in the political party, a party logically would contain many office-seeking factions or groups, each contesting for vacant offices to be filled at the state, county and local level. Under what conditions would these factions and groups join a coalition to present one candidate for an office, and under what conditions would the same coalition present candidates for several offices? Office-seeking groups under the party label may combine forces to present one candidate for an office because they believe cohesion is their only chance of winning. They also may unite to control the nominations for more than one office in the system for they may realize that a strong gubernatorial candidate, for instance, can bring others into office. In this case, the rudiments of a cohesive party structure begin to emerge (Schlesinger 1991, 151). If legislators support the governor's election because they see their own election chances bound up with those of the governor, the party has a measure of unity. For the governor, legislative cooperation is crucial to policy-making. Policies that please the electorate (or at least a majority of it) are crucial to the next election. As a result, in some states, a kind of symbiotic relationship develops between office seeking groups.

To the extent that the governors and legislators find it to their advantage to run on the same policy record, we have the makings of party government. This party government has come about because office-seekers must appeal to the electorate and believe that their next election depends on their performance in office. James Thompson, a Republican governor elected four times in Illinois (a competitive industrial state), had to offer enough benefits to workers and city dwellers to weaken their normal support for his Democratic opponent. He could not win the election by appealing to large farmers, industrialists, bankers and businessmen. There are not enough votes from those groups. After Thompson was elected, he had to present a 
program to the legislature to offer advantages to enough groups of voters to ensure reelection. The legislators will respond if they, in turn, believe that their next election depends on support for the governor's program.

A governor represents the totality of interests within the party. No single legislator or faction represents as wide a variety of interests. The governor's legislation is geared to please the state-wide constituency and, depending largely on his or her degree of control over the party, is passed, modified, or rejected. The governor is head of both political party and state government. The two roles are intertwined: the more successful one is as party leader, the more successful one is as head of state. A governor's ability to capture the loyalty of party leaders to build winning coalitions within the legislature is crucial to mastery over the decision-making process. This process allocates the burdens and benefits of the system. The governor's leadership can provide the link between the people and their problems and the extent and direction of resources that state government can allocate to these problems. A governing coalition exists if there is a leadership coalition that has the capacity both to nominate a governor and to command enough votes in the legislature to pass legislative requests.

\section{Party Government: American Style}

Thus one need not subscribe to the party responsibility model to recognize that there is a linkage between the electoral party and the party inside the government. In the coalition building model, parties are composed of men and women who operate under a party label and recruit, nominate and elect candidates for public office who are broadly representative of the party's voters and who (when elected) will present, enact, and implement programs that reflect the needs and demands of the same voters.

Most would agree that a strong state party involves the following activities:

1. It seeks to control the gubernatorial nomination through an endorsement process that produces candidates who are broadly in step with the program needs of the party's constituency.

2. During the election campaign, the gubernatorial candidate enunciates the program objectives of the party.

3. Once elected, the governor proposes a legislative program that is in agreement with the campaign promises.

4. The governor is able to enlist the support of all or most of his/her legislative party members to enact the program. 
Based on this model we would expect that in states where the governor's coalition is strong, as evidenced by nominating strength, the governor would be able to obtain loyalty from the legislators in the party. In states where the party is weak or divided, the governor will face a legislature in which sit remnants of the factions that opposed him or her in the nominating contest.

\section{The Structure of Party Coalitions}

Parties are a collective effort directed toward capturing pubic office and governing once that office is attained. But this effort takes many forms. In some states, the party organization is so weak that a political candidate receives the party label after a hard-fought primary and goes forth into the campaign with his or her own coalition, lacking any of the party elite. In other states, the party leadership and the candidate coalition are so strong that the candidate is supported from the start, and given organizational help for the nomination as well as for election and governing. A party organization or coalition is composed of elites from the factions and groups within the party.

\section{Factions and Groups}

State parties are characterized by the number, strength, and durability of the factions within them. Factions, in turn, are composed of groups that have interests in common and want to unite behind a candidate. V.O. Key defined a faction as

any combination. clique or grouping of voters and political leaders who unite at a particular time in support of a candidate. Thus, a political race with eight candidates will involve eight factions of varying size. Some factions have impressive continuity while others come into existence for only one campaign and then dissolve $(1950,16)$.

Thus, for Key, a faction was a subset of a political party that might or might not contest nominations over a series of primaries. Key also included the voters in his definition of faction, probably because he measured factional strength by primary voting strength. I do not include voters in my definition of a party faction, although votes are a resource that factional elites bring to the coalition. As I have said before, voters are choosers among factions and coalitions, not an organizational part of them.

Generally, three types of factional organization within parties are observed. The first is the unifactional party that features a leadership coalition that is continuous and can control nominations. The second is the 
bifactional party with two reasonably continuous groups, each claiming considerable electoral strength and the ability to compete for the nomination. Under this arrangement, the party leaders remain neutral or back their factional candidate. The third type of party is multifactional. Nominations often are contested by three or more candidates. Party leaders are weak and remain neutral, unless they are the instruments of the incumbent. It is commonly believed that the factions in multifactional parties are fluid, ephemeral, and without continuing geographical, economic or social bases.

The factional structure described above has been researched by several political scientists and modifications have been made. Southern parties are usually marked by transient factionalism, although there were examples of successful durable factions before 1950 (Black \& Black 1982). It is interesting to note that the cohesive northern party does not lack factions. It is able to compromise factional differences internally and present a united front in both the primary and general elections (Jewell and Olson 1982). There may be a single source of leadership, such as Governor Cuomo of New York. Alternatively, the leadership may be collegial, such as a state committee or an informal council of regional or county leaders, as among the Republicans of Pennsylvania. Cohesion may be engineered by a state convention, as in the Minnesota Democratic-Farmer-Labor party.

\section{Factions and Change}

The development of formal and stable factions within parties has been studied by Baer and Bositis (1988). They find that factions structure conflict and consensus within the political party. They are organized informally because they compete with other factions within the party, while they retain "the opportunity to negotiate, transact and compromise." Baer and Bositis claim that social movements, represented within the parties as factions, have brought about a change in party factionalism, and in many cases the substitution of new elites for the old. This means that American parties are permeable to outside groups that are moving into positions of leadership. The party has integrated the values and norms of the different groups, accounting for the increased cohesion noted by many scholars.

\section{Coalitions as Alliances Between Factions}

The main task of the party leaders is to manage the ever-present potential for factionalism and to channel the aspirations and energies of rival groups into a semblance of party unity. By my definition, this unity would be called a party coalition. It is harder to compromise economic and 
ideological factions than those which are ethnic, or geographic, and many parties remain bifactional. None of the factions within a multifactional party are cohesive enough or willing to form a party coalition. In the bifactional and multifactional parties, where the primary is the major decision point for determining the nomination, there is little to gain by joining a coalition if nomination can be had with as little as thirty percent of the vote.

\section{Parties as Instruments of Governing}

Is it true that party organization affects the quality and distribution of services to the people? Based on the party coalition model, we would expect that in states where the governor's electoral coalition is strong, the governor would be able to obtain loyalty from the legislators in the party. In states where the party is weak or divided, the governor will face a legislature in which sit remnants of the factions which opposed him or her in the primary contest. My research has found moderate to high correlations between the strength of electoral party coalitions and legislative party loyalty on the governor's program. To my knowledge, this is the only research that tests legislative voting loyalty on governors' program bills (Morehouse 1966, 1973, 1981, 246-252, 1992, 1993).

Very little research has been done on the relationship between the political efforts of party elites and gubernatorial candidates to capture the nomination, on the one hand, and their success at putting the party program into effect while in office, on the other. Several works have dealt descriptively with the legislative leadership of governors (Sabato 1983; Jewell and Olson 1988, 244-249; Muchmore and Beyle 1980). In Governors and Legislatures: Contending Powers (1990), Rosenthal describes executive-legislative jockeying as well as legislative independence from, or dominance over, the governor. He assumes institutional conflict as the title suggests, and does not focus on legislative voting on gubernatorial initiatives.

Until the research of Erikson, Wright, and McIver (1993) there was no proven connection between the preferences of the people and the policies that state legislatures made for them (1993). This research convinces us that there is a correlation between public opinion and state policy. Individual states differ in the ideological direction of their electorates, but the policies reflect this, with liberal states producing liberal policies and conservative states producing conservative policies.

What is fundamental for those studying party organization is their finding that party organizations matter. Within each party, there is a compromise between the electoral elites, those who run and get elected to office, and the activist elites, those whose values and ideologies define what the 
parties stand for. In this process, state parties position themselves at the public opinion midpoint for fear of electoral sanctions. And the parties' legislators reflect this midpoint in the policies they produce. This research sets the stage for compelling investigation of the coalition building efforts of party elites and factions in the struggle to nominate, elect and govern.

\section{The Research in this Volume and Future Research Priorities}

The papers in this volume fit into several broad, occasionally overlapping categories. One is the activities of the party that are aimed directly at nominating and electing candidates. A second category concerns the linkage of party organizations to other groups. A third area is the role of the party in formulating policy positions and governing the state. An underlying purpose of this approach is to provide a clearer understanding of state political party strengths: the kinds of activities that characterize a strong, effective party, and the factors that contribute to state party strength or weakness.

The purpose of this section is to summarize and put into perspective the articles included in this volume. Another purpose is to suggest additional topics that should have priority for those undertaking research on state political party organizations.

\section{Electoral Role of State Parties}

Obviously the electoral role of political parties is a critical one. A well organized political party organization will present to the voters the strongest possible slate of candidates. It also will provide as much assistance as possible to those candidates to enhance their chances of getting elected.

Recruiting Candidates. State political parties have a responsibility to recruit candidates, when necessary, for statewide, congressional, legislative and local office. Presumably the burden of this responsibility is greater for the minority party in a state than for one that is in the majority or is closely competitive. But even a majority party may need to recruit legislative or local candidates in areas of electoral weakness.

Little is known about the recruitment efforts of state or local party organizations, the governor, or legislative leaders in most states. On the one hand, the leaders of state and local party organization often respond to surveys by indicating that they are actively involved in recruitment (Cotter, Gibson, Bibby \& Huckshorn 1984; Gibson, Frendreis \& Vertz 1989). On the other hand, there is evidence of decline in the proportions of congressional and state legislative races that are contested at all, and that are closely 
contested-a trend that suggests ineffective recruitment efforts (Jewell and Breaux 1988; Weber, Tucker \& Brace 1991).

There is some evidence that state legislative leaders are playing a more active role in recruiting candidates for their party (Jewell and Whicker 1994). There are indications that those who are engaged in recruiting and supporting candidates are making greater use of statistical techniques to target winnable districts-a strategy that does not necessarily increase the number of contested races.

We would expect that aggressive and skillful recruitment efforts would be particularly necessary for southern state Republican parties to make electoral gains, particularly at the legislative level. This is the topic of William Cassie's paper, which examines Republican recruiting strategies for legislative races in six southern and border states. Cassie finds that party leaders in Georgia and Florida seek to contest as many seats as possible, while those in North Carolina, Texas, and Kentucky concentrate more on seats that appear to be winnable. In this second group of states, Republicans have made recent gains in seats without a comparable increase in the number contested. In Tennessee, Republican successes are concentrated more in traditional Republican areas.

Nominating Candidates. Obviously, American political parties are handicapped in their efforts to run a strong slate of candidates by their inability to control or significantly influence the outcome of most primary elections. The voters in primary elections may choose candidates who appeal to a narrow range of partisans or have little ability to attract votes from outside the party. In a limited number of states, the party organizations have tried to influence the outcome of primary elections by endorsing candidates before the primary. In some states the endorsement system is based on law; in others it is based on party rules.

In his paper below, Malcolm Jewell reviews trends in state party endorsements, specifically in gubernatorial races, since 1982. In recent years, several state parties have adopted a policy of endorsements, and several others have dropped the practice. In states with legal endorsements, the proportion of contested primaries continues to be small. But in states with both legal and informal endorsements, the proportion of contested races won by the endorsee has dropped from three-fourths to less than half. Endorsements are less effective in cases where the convention represents too narrow a political or ideological base.

Funding Candidates. As the cost of campaigning continues to grow and the success of candidates becomes increasingly dependent upon the amount of money they can raise, the most valuable assistance a party organization can provide to its candidates is to help them raise money. This can be 
accomplished in several ways. The party may train candidates in fundraising, may provide them with lists of contributors, or may directly raise money for the candidates. The party also may provide candidates with services (such as consultants and polling data), and thus reduce their need for funds.

In allocating more resources and assistance to some candidates than to others, the political party establishes its priorities and implements its strategy. The party organization's ability to accomplish these goals obviously depends upon its ability to raise large sums of money and, on occasion, to advise PACs and individuals on how they should allocate their funds.

One of the most significant developments in recent years has been the growth of legislative party campaign committees that raise funds and allocate them to candidates. Some are party caucus committees and others are run by individual leaders, but in either case the legislative leaders usually raise most of the funds and determine their allocation.

The paper by David Breaux and Anthony Gierzynski describes the strategies used in the 1988 elections by lower-house legislative campaign committees in eleven states. They find that contributions from such committees are targeted more on close races and on nonincumbent and open-seat candidates than are funds from other sources. They demonstrate with a simulation that increased funding by legislative campaign organizations would reduce the funding gap between incumbents and challengers, thus increasing competition.

Party Organizational Response to Electoral Change. Not much is known about the conditions under which political party organizations may grow more or less active/effective. This question is particularly interesting to students of southern politics, because there is so much variation in the effectiveness of state party organizations, even in states where the Republican party has had comparable success in national elections.

Andrew Appleton and Daniel Ward seek to provide some answers to this puzzle by providing case studies of the Texas and Arkansas Republican parties. Both parties had the opportunity to take advantage of an unexpected electoral breakthrough: the elections of Senator John Tower in Texas in 1961 and of Governor Winthrop Rockefeller in Arkansas in 1966. The authors explain how the Texas Republicans capitalized on Tower's election to build a viable party organization, while the Arkansas Republicans failed in this effort and were not significantly better organized at the end of Rockefeller's tenure than they had been in 1966.

Other Research Priorities. The opportunities for research on the electoral role of state parties are almost limitless. Perhaps the most obvious opportunity is in southern states, where the greatest changes are occurring. 
It has been more than forty years since Eisenhower first carried a number of southern states, and some thirty years since Barry Goldwater and Richard Nixon made further inroads in the South. Until very recently the progress of southern and border Republican parties in winning state and legislative races has been slow and uneven. We need to learn more about these Republican parties; specifically, their organizational strength, the strategies they are following, and their effectiveness. As we begin to understand better the patterns of change in southern states, we can apply these lessons to states in other regions where there is some evidence of change.

\section{Linkages of State Party Organizations to Other Groups}

If scholars concentrate their attention only on state party organizations, they will miss much of the partisan activity that is occurring. The success of a modern state party organization is measured not only by what that organization does, but by how effectively it works with other partisan groups and with groups that are potential allies of the party organization. Two of the papers in this volume examine the linkages of state party organizations with national campaign organizations and with legislative campaign committees. The third sheds light on the linkages between parties and interest groups, and, specifically, the role of party activists who have strong loyalties to interest groups.

Linkages between State Parties and National Campaign Organizations. The success of a presidential campaign in a particular state may depend upon the strength of the state party organization and the ability of the state and national organizations to work together effectively. If the presidential race in the state is tight, this factor obviously could be decisive. Despite the importance of this question, non-anecdotal evidence concerning it is meager.

In her paper below, Barbara Trish examines the integration of the 1988 and 1992 presidential campaign organizations in Indiana and Ohio with the state and local party organizations in those states. These states have strong state and local parties and competitive two-party politics. She finds that in both states the Republican organizations were better integrated in 1988, and the Democratic ones were better integrated in 1992-a contrast she attributes to differences in organizational skills between the Dukakis and Clinton campaigns. In both years the organizational integration was higher in Ohio, a difference attributed to the strength and relative autonomy of those urban party organizations in Ohio that could work directly with the presidential campaigns. The fact that the election was expected to be tighter in Ohio than in Indiana also contributed to this contrast. 


\section{Linkages between State Parties and Legislative Campaign Committees.} The increasing activity of state legislative campaign committees raises questions about the relationships between these groups and state (and local) party organizations. Do legislative campaign committees develop to fill a vacuum because the state party fails to support legislative candidates? Or do they arise in more competitive states where the state party already may be strong? Are the activities of these groups complementary or competitive? If both groups engage in targeting and set priorities for candidate funding, do they ever work at cross purposes?

In his paper on the development of legislative campaign committees, Daniel Shea rejects the argument that they were developed to fill a vacuum caused by state or local party organization inaction. He suggests instead that these committees arose in the more professionalized legislatures, where the stakes were higher and the leadership had access to more resources. The rising cost of elections and close partisan margins in the legislature also help explain the trend. He believes that they sometimes were developed in response to the strengthening of state party organizations. He provides examples of cases where the legislative committee disagreed with the state or local party about which candidate to support in a primary, when the party had no incumbent running.

One of the implications of this study is that legislators elected with the support of legislative leaders may be more independent of the governor than are those elected with assistance from the state party organization that may be controlled by the governor.

Linkage of State Parties to Interest Groups. The linkages between state political parties and interest groups is one of the most fascinating topics in state politics, and one that deserves much attention from political scientists. We know that each of the parties, at both the national and state level, has various kinds of ties to particular organized groups. Democratic parties in many states, for example, are allied with labor unions, teachers, and minority ethnic groups, among others. Organized interest groups provide voting cues for their members, and workers for campaigns. They provide funding directly for a party's candidates, and also provide funds for state, local, and legislative party committees. They may cooperate with a party in planning strategy and targeting races.

Many of today's party activists, probably more than those twenty years ago, become active in the party because of their membership in an interest group and their strong interest in particular issues. Examples are members of unions, environmental groups, pro-life and pro-choice groups, and members of the religious right. They may be seeking to affect the party's platform and perhaps also its choice of candidates. 
Denise Baer and Julie Dolan utilize an extensive 1988 survey of party activists in their paper exploring the linkage between organized groups and state and local parties, a connection they describe as "intimate." They find that an overwhelming proportion of party activists belong to at least one group and usually two or three; and there are sharp contrasts in the group memberships of Democrats and Republicans. These memberships are associated with differences in ideology. The importance of these loyalties was shown by the substantial proportion of activists who say that they represent particular groups in their party work. They conclude that the strong loyalties to organized groups shared by a large proportion of party activists help to explain why the parties offer real alternatives to voters.

The paper by Baer and Dolan suggests the importance of learning more about how interest groups operate within parties, what their goals and strategies are. Under what conditions is it likely that a strong party faction linked to an interest group will have success in nominating a candidate who cannot appeal to a broader electorate? The role of the Christian right in some state and local parties would make a good starting place.

\section{Parties as Agenda-Setters and Instruments of Governing}

The recent growth of partisanship in roll-call voting at the congressional level is one piece of evidence that partisan control of the national government significantly affects agenda-setting and policy decisions. But there is a serious shortage of research on the impact of partisanship upon decision-making at the state level.

State Party Platforms. We know much about national party platformshow they are developed, what they cover, and how much they differ between the parties. We know almost nothing about state party platformsnot even how extensively they are adopted by state parties. We do not know how much Democratic and Republican platforms in a state differ, or how well they correlate with the positions taken by legislators and governors. This topic is important to the study of state parties because a platform adopted by a state committee or platform offers one way in which voters may distinguish between parties, as well as one vehicle with which party activists may influence policy.

In his paper below, Joel Paddock examines the content of platforms adopted by 40 Democratic parties and 34 Republican ones during the 198992 election cycle. He finds some differences in the issues emphasized by platforms of the two parties (along expected directions), and he measures the average ideological difference on each major category of issue. He also finds that there are much greater interparty ideological differences in some 
states than in others. Finally, he measures the correlations between the ideological orientations of the platforms and those of party elites and the public (as measured by Wright, Erikson, and McIver); the correlations between party elites and platforms is higher for Democrats.

The Impact of State Party Elite Ideology. If state party elites are ideologically distinct, as suggested by Baer and Dolan and some other authors, what difference does it make for state policy-making? Gerald Wright, Robert Erikson, and John McIver provide some convincing answers in their paper. The data come from surveys of two types of party elitescandidates for office, and party activists-and from surveys of the public in each state.

They find that state party activists are ideologically distinct and strongly policy-motivated. A party's candidates are significantly influenced both by public opinion in the state and by the ideological viewpoints of party activists. The activists, in effect, pull the candidates away from the viewpoints of the median vote, and as a result the parties offer contrasting policy proposals to the voters. While policy outputs are influenced primarily by state public opinion, they also are influenced on some issues by the ideology of party elites.

Other Research Priorities. There are few comparative studies of how gubernatorial candidates go about coalition building for the nomination, election and governing. The next step is to discover how they do this and what ambitions, resources and political arrangements contribute to this effort. To what extent do governors, once in office, move to take control of the party organization? How is this done? Do they succeed, or meet resistance? And, once in charge, what use do they make of the party organization? To what extent do governors get involved in party activities such as fund-raising, recruiting candidates, or trying to affect the endorsement process? How does the governor provide effective leadership of the legislative party?

Very little research in recent years has been done on the role of partisanship in state legislatures. Rosenthal has argued that many legislatures are becoming more partisan (1993). We might expect parties to be more important in decision-making because more legislatures have relatively close two-party competition. But we frequently are told that individual legislators are becoming more independent and less subject to discipline. There is some evidence that the party caucuses are often a strong tool of the leadership, and we know leaders now provide more funding for candidates than in the past (Jewell and Whicker 1994; Gierzynski 1992).

In the 1950s and 1960s, a number of studies measuring partisanship in state legislative roll-call voting were published. This type of research seems 
to have vanished almost entirely from the literature, despite the increasing availability of computers with which to reduce the drudgery of such research. It is time for renewed attention to studying legislative roll-call voting, and particularly the role of partisanship.

\section{REFERENCES}

Advisory Commission on Intergovernmental Relations. 1986. The Transformation in American Politics: Implications for Federalism. Washington, DC: Advisory Commission on Intergovernmental Relations.

Baer, Denise L. and David Bositis. 1988. Elite Cadres and Party Coalitions: Representing the Public in Party Politics. Westport: Greenwood Press.

Black, Earl and Merle Black. 1982. Successful Durable Democratic Factions in Southern Politics. In Lawrence W. Moreland et al., eds., Contemporary Southern Political Attitudes and Behavior. New York: Praeger.

Cotter, Cornelius P., James L. Gibson, John F. Bibby, and Robert J. Huckshorn. 1984. Party Organizations in American Politics. New York: Praeger.

Downs, Anthony. 1957. An Economic Theory of Democracy. New York: Harper and Row.

Epstein. Leon D. 1986. Political Parties in the American Mold. Madison: University of Wisconsin Press.

1993. Research Directions. American Review of Politics 14: 467-480.

Erickson, Robert S., Gerald C. Wright, and John P. McIver. 1993. Statehouse Democracy: Public Opinion and Policy in the American States. New York: Cambridge University Press.

Gibson, James L., John P. Frendreis, and Laura L. Vertz. 1989. Party Dynamics in the 1980s: Change in County Party Organizational Strength, 1980-1984. American Journal of Political Science 33: 67-90.

Gierzynski, Anthony. 1992. Legislative Party Campaign Committees in the American States. Lexington: University Press of Kentucky.

Jewell, Malcolm E. and David M. Olson. 1982. American State Political Parties and Elections, rev. ed. Homewood, IL: Dorsey Press.

1988. American State Political Parties and Elections, third ed. Chicago: Dorsey Press.

Jewell. Malcolm E. and David Breaux. 1988. The Effect of Incumbency on State Legislative Elections. Legislative Studies Quarterly 13: 49.5-514.

Jewell, Malcolm E. and Marcia Lynn Whicker. 1994. Legislative Leadership in the American States. Ann Arbor: University of Michigan Press.

Key, V.O. Jr. 1950. Southern Politics in State and Nation. New York: Knopf.

Morehouse. Sarah McCally. 1966. The Governor and His Legislative Party. American Political Science Review 60: 923-942.

1973. The State Political Party and the Policy Making Process. American Political Science Review 67: 55-72.

1981. State Politics, Parties and Policy. New York: Holt Rinehart and Winston.

1992. Legislative Party Voting for the Governor's Program. Paper presented at the annual meeting of the American Political Science Association, Chicago, IL.

1993. Voting for the Governor's Program: Party Versus Constituency. Paper presented at the annual meeting of the Southern Political Science Association, Savannah, GA.

Muchmore, Lynn and Thad L. Beyle. 1980. The Governor as Party Leader. State Government 53: 121-124.

Pomper. Gerald M. 1992. Passions and Interests. Lawrence. KS: University Press of Kansas. 
Ranney. Austin. 1962. The Doctrine of Respcnsible Party Government. Urbana: University of Illinois Press.

Rosenthal. Alan. 1990. Governors and Legislatures: Contending Powers. Washington DC: Congressional Quarterly Press.

1993. The Legislative Institution-In Transition and at Risk. In Carl E. Van Horn, ed., The State of the States, second ed. Washington. DC: Congressional Quarterly Press.

Sabato, Larry. 1983. Goodbye to Goodtime Charlie, second ed. Washington. DC: Congressional Quarterly Press.

Schlesinger, Joseph A. 1991. Political Parties and The Winning of Office. Ann Arbor, MI: University of Michigan Press.

Weber, Ronald E., Harvey J. Tucker. and Paul Brace. 1991. Vanishing Marginals in State Legislative Elections. Legislative Studies Quarterly 16: 29-48. 